\title{
The Establishment Clause and Public Schools
}

\author{
Clifford Fisher ${ }^{1} \&$ Ethan Hicks ${ }^{2, *}$ \\ ${ }^{1}$ Clinical Professor, Krannert School of Management, Purdue University, USA \\ ${ }^{2}$ Krannert School of Management, Purdue University, USA \\ *Corresponding author: Krannert School of Management, Purdue University, USA
}

Received: April 23, 2018 Accepted: July 2, 2018 Published: July 20, 2018

doi:10.5296/jsr.v9i2.13449 URL: https://doi.org/10.5296/jsr.v9i2.13449

\begin{abstract}
The purpose of this report is to explore and elucidate the application of the Establishment Clause to the activities of U.S. public schools, primarily through an examination of relevant case law. It is intended to facilitate an understanding of the fundamental principles and nuances of this legal issue throughout its history. The first sections offer a glimpse of the history of the Establishment Clause itself, including a discussion of the historic Supreme Court cases that laid the foundation off of which many of the decisions to be examined are built. Subsequent sections, organized by specific issue, analyze Establishment Clause cases that involve public schools, and have two primary objectives: to determine established precedents, and to discover trends and inconsistencies. Specific issues addressed include evolution and creationism in curricula, released time programs, prayer in class, and recitation of the Pledge of Allegiance.
\end{abstract}

Keywords: Establishment Clause, public schools, First Amendment, religion 


\section{Introduction}

The first clause of the First Amendment to the United States Constitution is known as the Establishment Clause and reads: "Congress shall make no law respecting an establishment of religion."(Note 1) According to Thomas Jefferson, its purpose is to erect "a wall of separation between church and State," (Note 2) to promote a disconnect between the institutions of government and religion in American society. In the past half century, the Supreme Court of the United States and lower courts have heard countless cases involving claims that this prohibition imposed on the government has been violated, and many of such cases have involved alleged violations of the clause in the nation's public school systems. Considering that the minds of elementary and secondary students are "impressionable and their attendance involuntary," the Supreme Court has stated that it "has been particularly vigilant in monitoring compliance with the Establishment Clause" in those cases involving students in elementary and secondary public schools. (Note 3)

The Court has historically provided several legal tests to determine whether or not a particular government action is in violation of the Establishment Clause, and has employed them to address potential violations in public schools. Issues that have been brought before courts include legislative mandates relating to evolution and creation in curricula, prayer in classrooms and at school events, school endorsement of religious instruction, compulsion of students to recite the Pledge of Allegiance, religious holidays, and religious clubs. Cases involving several of these issues and the reasoning provided by courts in their decisions will be analyzed, but predictive trends in these decisions are oftentimes difficult to identify due to significant inconsistencies in judicial opinions. According to Ronna Greff Schneider, Professor of Law at the University of Cincinnati College of Law and former Chairperson of the Education Law Section of the Association of American Law Schools, "the Court's Establishment Clause jurisprudence, at least in the last two decades, has lacked clarity, certainty, and consistency."(Note 3)

\section{Establishment Clause History and Legal Tests}

\subsection{Incorporation and the Establishment Clause Test}

The Bill of Rights, consisting of the first ten Amendments to the United States Constitution, was adopted in 1791. However, in accordance with the ruling in Barron v. Baltimore (1833), (Note 4) the substantive protections of the Bill of Rights did not apply to state governments for over one hundred years after its adoption. Application to the state governments eventually developed via the application of another Constitutional Amendment. During the Reconstruction Era following the American Civil War, the Fourteenth Amendment was adopted in 1868. Section 1 of this Amendment provides in part: "[N]or shall any State deprive any person of life, liberty, or property, without due process of law." (Note 5) It was the employment of this Due Process Clause in Gitlow v. New York (1925) (Note 6) that led to the emergence of the Incorporation Doctrine, through which the Supreme Court of the United States began to finally apply with full force the Bill of Rights to state governments. Because 
public schools are directly controlled by the state governments, it was not until this change started to take full effect in the middle of the 20th century that the Establishment Clause was first applied to public schools. (Note 7)

The U.S. Supreme Court first held that the Establishment Clause is one of the freedoms that fall under protection of the Due Process Clause of the Fourteenth Amendment in Everson v. Board of Education (1947). The issue of this case was whether or not New Jersey was prohibited by the First Amendment from using tax funds to pay for the bus fares of children who attend parochial schools. The court ruled that the First Amendment did not provide such a prohibition, with the reasoning that "the legislation did no more than provide a general program to help parents get their children, regardless of their religion, safely and expeditiously to and from accredited schools." (Note 8) More significant than the immediate outcome of the case, Justice Hugo L. Black, in the majority opinion of Everson, expressed what came to be known as the Establishment Clause Test:

- Neither a state nor the federal government can set up a church.

- Neither can pass laws which aid one religion, aid all religions nor prefer one religion over another.

- Neither can force nor influence a person to go to or to remain away from church against his will or force him to profess a belief or disbelief in any religion.

- No person can be punished for entertaining or professing religious beliefs or disbeliefs, for church attendance or non-attendance.

- No tax in any amount, large or small, can be levied to support any religious activities or institutions, whatever they may be called or whatever form they may adopt to teach or practice religion.

- Neither a state nor the federal government can openly or secretly participate in the affairs of any religious organizations or groups and vice versa. (Note 9)

This test of constitutionality with respect to the Establishment Clause has since become outdated and was slowly replaced by more practical tests. The three most significant of such judiciary devices established by the Court have informed many of the judgements in Establishment Clause cases: the Lemon Test, the Endorsement Test, and the Coercion Test.

\subsection{The Lemon Test}

In the 1971 Supreme Court case Lemon v. Kurtzman, appellants challenged state statutes that provided aid to church-related elementary and secondary schools as a violation of the Establishment Clause. The Court ruled in favor of the appellants, declaring such statutes unconstitutional. (Note 10) In its decision, it described what came to be known as the Lemon Test. Although this test has been subject to criticism, it has often been viewed as the standard of judicial review in Establishment Clause cases, and many courts continue to use it as the primary test in such cases.(Note 7) The test puts forth three questions, and a negative answer to any one of them establishes unconstitutionality for violation of the Establishment Clause. 
The three questions are:

- Does the challenged law, or other governmental action, have a bona fide secular (non-religious) or civic purpose?

- Does the primary effect of the law or action neither advance nor inhibit religion? In other words, is it neutral?

- Does the law or action avoid excessive entanglement of government with religion?(Note 9)

In Agostini v. Felton (1997), the Supreme Court considered an injunction against a federally funded program in which public school teachers are sent to parochial schools to provide education to disadvantaged children. Interestingly, the injunction was originally the result of a previous decision of the Supreme Court. However, the court overruled its prior decision, reasoning that although the instruction was given on the premises of sectarian schools by government employees, it was neutral in nature and pursuant to a program containing sufficient safeguards. (Note 11) In the course of its decision, the Court modified the Lemon Test. The change essentially consisted of providing criteria for evaluating satisfaction of the effect prong, but with the excessive entanglement prong as one of such criteria instead of as a separate prong of the test. The new criteria for consideration of the effect prong are (1) government indoctrination, (2) defining the recipients of government benefits based on religion, and (3) excessive entanglement between government and religion. So to be clear, the revised version of the Lemon Test consists of this amended effect prong and the original purpose prong. (Note 7)

\subsection{The Endorsement Test}

In the 1984 case Lynch v. Donnelly, the Supreme Court reviewed an injunction prohibiting a city from including a crèche in its annual holiday display. The Court reversed this judgement, reasoning that "the city had not impermissibly advanced religion." It was the concurring opinion of Justice Sandra Day O'Conner in this case that first proposed the Endorsement Test, which asks whether or not the particular government action constitutes an endorsement of religion. She elucidates the central concern of the test as a determination of whether or not the particular government action conveys "a message to non-adherents that they are outsiders, not full members of the political community, and an accompanying message to adherents that they are insiders, favored members of the political community." (Note 12) This test is today often applied in "situations where the government is engaged in expressive activities." (Note 7) It so happens that many of the issues relating to the Establishment Clause in public schools, such as prayer in graduation ceremonies, religious displays in classrooms, and religion in the curriculum, are such situations. Thus, the Endorsement Test is particularly pertinent to this discussion.

\subsection{The Coercion Test}

In Allegheny County v. ACLU (1989), the Supreme Court considered a very similar situation as it did in Lynch v. Donnelly, but proceeded very differently in its decision. The Court upheld 
a restriction on the display of a crèche on government property, reasoning that "the display supported and promoted the Christian praise to God." Justice Anthony Kennedy outlined the Coercion Test in his dissenting opinion as follows: The government does not violate the establishment clause unless it (1) "coerce[s] anyone to support or participate in any religion or its exercise" or (2) "give[s] direct benefits to religion in such a degree that it in fact establishes a [state] religion or religious faith, or tends to do so." (Note 13) This is a decidedly narrow application of the Establishment Clause, and has been subject to varying interpretations and implementations.

Justice Kennedy again proposed the Coercion Test in the U.S. Supreme Court case Lee v. Weisman (1992). This case was a question of whether or not public school system officials are permitted to invite members of the clergy to offer prayers as part of formal school graduation ceremonies. The Court's majority opinion, written by Justice Kennedy and invoking the Coercion Test, found that this practice is inconsistent with the Establishment Clause. Justice Antonin Scalia sharply disagreed and wrote in the dissenting opinion, but he too came to his decision via application of the Coercion Test. (Note 14) This demonstrates that interpretations of this test can vary widely, which is one of the major reasons it is less commonly employed.

\subsection{The Neutrality Standard}

While today the Court often looks to the Endorsement Test in cases where the government is engaged in expressive activities, matters involving use of government funds are increasingly decided using the standard of neutrality. In the context of the Establishment Clause, neutrality means that the government gives the same treatment to religious groups as it does to other similarly situated groups. Although it has evolved since, this concept of neutrality was first cited as a guiding principle in Everson, where neutrality was described to mean that government is "neither ally nor adversary" of religion.(Note 7)

In Zelman v. Simmons-Harris (2002), a scholarship program established by the state of Ohio was challenged for violation of the Establishment Clause. The program provided tuition aid for students to attend a participating public or private school of their parent's choosing. The Court held that the program was entirely neutral with respect to religion, and therefore did not violate the Establishment Clause. The plurality opinion reasoned that "it provided benefits directly to a wide spectrum of individuals, defined only by financial need and residence in a particular school district," and that "it permitted such individuals to exercise genuine choice among options public and private, secular and religious." In this decision, the Court defined neutrality as even-handedness in terms of who may receive government aid. (Note 15) Accordingly, indirect aid to a religious group appears constitutional, as long as it is part of a neutrally applied program that directs the money through a third party who ultimately controls the destination of the funds. (Note 7) 


\section{Specific Establishment Clause Issues in Public Schools}

\subsection{Evolution and Creationism in Curricula}

The intense conflict of evolution vs. creationism has pervaded American society and culture in numerous ways. One of its more prominent impacts has been on the discussion of public school curricula. Some state legislatures and school boards have even enacted statutes or implemented policies that mandate creationism be included in the science curricula of public schools. U.S. courts have then been tasked with determining the constitutionality of such mandates. The principal question is whether or not such a mandate constitutes a violation of the Establishment Clause. The Supreme Court has decisively ruled that it does indeed constitute such a violation. In Epperson v. Arkansas (1968), a public school teacher challenged the constitutionality of an Arkansas law that criminalized the teaching of evolution and subjected her to dismissal from her position. The Court ruled in favor of the teacher, as it determined that the law was written based upon motives that violated the Establishment Clause. The opinion provided that "the law's effort was confined to an attempt to blot out a particular theory because of its supposed conflict with the Biblical account." (Note 16) Providing this reason in support of holding the law in violation of the Establishment Clause, that the purpose of the law was not of a bona fide secular nature, appears to be an implicit reference to the purpose prong of the Lemon Test.

Understanding that outright prohibition of teaching evolution in schools is held to be unconstitutional, lawmakers have attempted to mandate that whenever evolution is taught in public schools, creationism be taught alongside it. In Edwards v. Aguillard (1987), the Court inspected the "Louisiana Creation Act," which required the state's public schools to give "balanced treatment" to "creation science" and "evolution science." The Court applied the Lemon Test and determined that the statute failed because "(a) the statute was designed either to promote a particular religious tenet or to prohibit the teaching of a scientific theory disfavored by certain religious sects, and (b) the statute did not further the legislature's stated goal of protecting academic freedom." The law was therefore held to be inconsistent with the Establishment Clause. (Note 17) The Court's opinion has been clear with regard to statutes that mandate public schools to advance creationism or to not advance evolution: it is a violation of the Establishment Clause.

\subsection{Released Time}

In released time programs, schools allow students, with the permission of a parent, to leave their normal studies in order to participate in some religious instruction. Two Supreme Court cases involving released time programs illustrate the Court's distinction of when the programs violate the Establishment clause and when they do not. The key issue is the degree to which school resources are involved in the religious instruction of the program, but the line between excessive and permissible involvement can be difficult to determine.

Instructed devotional study of religion in public school classrooms during normal school hours seems to be a clear example of excessive entanglement between government and religion, but public school systems have attempted to use released time programs to do just 
that. In 1948, the Supreme Court decided McCollum v. Board of Education, in which a school board in Illinois set up a released time arrangement in which students whose parents consented could participate. In the program, students attended religious instruction classes conducted by outside teachers chosen by a religious council. The classes took place in the school building during regular school hours. Attendance was recorded as if the classes were like any other, and if students were not attending the religious instruction classes, they were required to continue their regular studies. Drawing from its decision in Everson v. Board of Education, the Court ruled that such a program is in violation of the Establishment Clause. (Note 18)

Zorach v. Clauson (1952) was also a case involving a released time program, but there were key differences between it and McCollum. Zorach involves the schools of New York City, which had a program which permitted, with permission of parents, students to leave during the school day in order to attend religious courses operated outside the school building by, and at the expense of, a religious body. Because the religious instruction occurred outside of the school buildings with extremely minimal involvement of school officials, the Court found that the program did not violate the Establishment Clause. It found no evidence that the program involved the use of coercion to encourage religiosity. The Court stressed that the Establishment Clause did not "require the government to be hostile to religion and to throw its weight against efforts to widen the effective scope of religious influence." (Note 19)

\subsection{Prayer in Class}

Engel v. Vitale (1962) was a Supreme Court case in which the policy adopted by the state of New York to create a "brief, denominationally neutral" prayer to be voluntarily recited in public school classrooms daily was challenged. The court ruled that the public school system's facilitating of the recitation of an official prayer is "entirely inconsistent" with the Establishment Clause. It went on to say that "the constitutional prohibition of laws establishing religion meant that government had no business drafting formal prayers for any segment of its population to repeat in a government-sponsored religious program." The Court explained that participation being entirely voluntary did not matter. The school did not simply avoid impeding religion, but actively endorsed it. Alluding to the Endorsement Test, the opinion of the Court made clear that any endorsement of a religious activity (such as prayer) by a public school system is a violation of the Establishment Clause. (Note 20)

The 1985 Supreme Court case Wallace v. Jaffree also involved the idea of prayer in public school classrooms. The issue of the case was whether or not a statute authorizing public school teachers to conduct a period of silence each school day for the purpose of "meditation or voluntary prayer" violated the Establishment Clause. The Court determined that the intent of the statute was to "convey a message of state approval of prayer in the public schools." It therefore declared the law unconstitutional due to violation of the Establishment Clause. (Note 21) Evidenced by these two cases, the Supreme Court has exercised caution when examining public school policies that may convey an endorsement of prayer or other religious activity. It has consistently shown a desire for school officials to be as uninvolved in student religious activities as possible, especially in the classroom. 


\subsection{Pledge of Allegiance Recitation}

In 2002, the United States Court of Appeals for the Ninth Circuit decided Newdow v. United States Cong. in which a parent challenged the policy of a school district to require teachers to lead students in a recitation of the Pledge of Allegiance every morning. He claimed that this policy, because of the words "under God" in the pledge, violates the Establishment Clause. The court ruled in his favor. The decision provided that the words "under God" in the pledge is a profession of a religious belief, and that the pledge "aimed to inculcate in students a respect for the ideals set forth in the pledge." It therefore ruled that the school district policy impermissibly coerced a religious act, violating the Establishment Clause. (Note 22)

However, the school district appealed this decision, and in 2010 the court reversed it. In this reversing decision, the court found that the pledge was one of allegiance to the United States, and not to God or to any religion. In its assessment of compliance with the purpose prong of the Lemon Test, the court wrote that the purposes of the pledge and the school district's policy were patriotic, not religious. In its assessment of compliance with the effect prong of the Lemon Test, the court wrote that neither the pledge nor the policy involved any entanglement with religion, and that the effect of neither the pledge nor the policy was to advance nor inhibit religion. The prior decision ruling the policy unconstitutional for violation of the Establishment Clause was therefore reversed. (Note 23)

The United States Court of Appeals for the First Circuit handed down a similar decision in Freedom from Religion Found. v. Hanover Sch. Dist. (1st Cir. 2010). The matter presented to the court was whether or not the Establishment Clause was violated by the New Hampshire School Patriot Act, which required that the state's public schools authorize a period during the school day for students to voluntarily participate in the recitation of the Pledge of Allegiance. (Note 24) The court held that the Act did not violate the United States Constitution. Specifically, the court found that although the phrase "under God" had some religious content, that was not determinative of the Act's constitutionality since the Constitution did not require complete separation of church and state. Furthermore, the court found that taken in the context of the words of the whole Pledge, the phrase "under God" did not convey an unconstitutional message of endorsement since they appeared in a pledge to a flag, accompanied by no other religious language or symbolism. (Note 25) The prevailing precedent in U.S. courts seems to be that public school district policies endorsing recitations of the Pledge of Allegiance during class, in which students' active participation is entirely optional, do not violate the Establishment Clause.

\section{Conclusion}

Public schools have throughout recent history been involved in many allegations of violation of the Establishment Clause of the First Amendment to the Constitution of the United States. Since Incorporation in the middle of the 20th Century, and especially more recently, the Supreme Court and lower courts have in many cases applied a very restrictive interpretation of the clause on public schools. The reason for this seems to be that public schools, as both a 
component of the State and a major influencer on the young citizens of the nation, have a great responsibility to maintain neutrality on religious issues. The courts, in their use of the Lemon Test, the Endorsement Test, the Coercion Test, and the standard of neutrality, have tried to ensure that all policies and activities of public schools live up to this responsibility without infringing upon the rights of students and staff, and without harming the ability of the schools to function.

Sometimes the Supreme Court's decisions on the matter, however, are not particularly clear, are inconsistent with its other decisions, or are not articulated in a way that makes them easily applicable to other Establishment Clause cases. While the Court has made clear its opinion of certain specific issues, decisions in Establishment Clause cases as a whole lack a cohesive set of unambiguous guidelines with which future decisions may be predicted. A large portion of the blame can be attributed to the lack of consensus on the best legal test to determine whether or not a particular government action violates the clause. While the Endorsement Test and standard of neutrality have increasingly emerged as the chief methods in certain types of Establishment Clause cases, they are not especially useful in others. The Lemon Test also remains an option and has been employed in several twenty-first century cases. Until a legal test becomes distinguished as the principal approach to an Establishment Clause case, decisions in the Supreme Court and lower courts will likely remain unpredictable and difficult to apply generally.

\section{References}

Agostini v. Felton, 521 U.S. 203, 117 S. Ct. 1997 (1997)

Barron v. Baltimore, 32 U.S. 243 (1833)

Cty. of Allegheny v. ACLU, 492 U.S. 573, 109 S. Ct. 3086 (1989)

Edwards v. Aguillard, 482 U.S. 578, 107 S. Ct. 2573 (1987)

Engel v. Vitale, 370 U.S. 421, 82 S. Ct. 1261 (1962)

Epperson v. Arkansas, 393 U.S. 97, 89 S. Ct. 266 (1968)

Establishment Clause Overview, Newseum Institute (2011), http://www.newseuminstitute.org/first-amendment-center/topics/freedom-of-religion/est ablishment-clause-overview/ (last visited Feb 22, 2018).

Everson v. Bd. of Educ., 330 U.S. 1, 67 S. Ct. 504 (1947)

Freedom from Religion Found. v. Hanover Sch. Dist., 626 F.3d 1 (1st Cir. 2010)

Getting Help With Their Homework: Schools, Lower Courts, and the Supreme Court Justices Look for Answers Under the Establishment Clause, 53 ADMIN. L. REV. 943

Gitlow v. New York, 268 U.S. 652, 45 S. Ct. 625 (1925)

Ill. ex rel. McCollum v. Bd. of Educ., 333 U.S. 203, 68 S. Ct. 461 (1948)

Lee v. Weisman, 505 U.S. 577, 112 S. Ct. 2649 (1992) 
Lemon v. Kurtzman, 403 U.S. 602, 91 S. Ct. 2105 (1971)

Lynch v. Donnelly, 465 U.S. 668, 104 S. Ct. 1355 (1984)

N.H. Rev. Stat. Ann. § 194:15-c

Newdow v. Rio Linda Union Sch. Dist., 597 F.3d 1007 (9th Cir. 2010)

Newdow v. United States Cong., 328 F.3d 466 (9th Cir. 2002)

Tests Used by the Supreme Court in Establishment Clause Cases, First Amendment Schools (2018), http://www.firstamendmentschools.org/resources/handoutla.aspx?id=14077 (last visited Feb 22, 2018).

Thomas Jefferson, Jefferson's Letter to the Danbury Baptists Library of Congress Information Bulletin (1998), https://www.loc.gov/loc/lcib/9806/danpre.html (last visited Feb 22, 2018).

USCS Const. Amend. 1

USCS Const. Amend. 14

Wallace v. Jaffree, 472 U.S. 38, 105 S. Ct. 2479 (1985)

Zelman v. Simmons-Harris, 536 U.S. 639, 122 S. Ct. 2460 (2002)

Zorach v. Clauson, 343 U.S. 306, 72 S. Ct. 679 (1952)

\section{Notes}

Note 1. USCS Const. Amend. 1

Note 21. Thomas Jefferson, JEFFERSON'S LETTER tO THE DANBURY BAPTISTS Library of Congress Information Bulletin (1998), https://www.loc.gov/loc/lcib/9806/danpre.html (last visited Feb 22, 2018).

Note 3. Getting Help With Their Homework: Schools, Lower Courts, and the Supreme Court Justices LOOK FOR Answers Under the Establishment Clause, 53 ADMIN. L. REV. 943

Note 4. Barron v. Baltimore, 32 U.S. 243 (1833)

Note 5. USCS Const. Amend. 14

Note 6. Gitlow v. New York, 268 U.S. 652, 45 S. Ct. 625 (1925)

Note 7. Establishment Clause Overview, Newseum InstituTe (2011), http://www.newseuminstitute.org/first-amendment-center/topics/freedom-of-religion/establis hment-clause-overview/ (last visited Feb 22, 2018).

Note 8. Everson v. Bd. of Educ., 330 U.S. 1, 67 S. Ct. 504 (1947)

Note 9. Tests Used by the Supreme Court in Establishment Clause Cases, FIRST AmENDMENT SCHOOLS (2018), http://www.firstamendmentschools.org/resources/handout1a.aspx?id=14077 
(last visited Feb 22, 2018).

Note 10. Lemon v. Kurtzman, 403 U.S. 602, 91 S. Ct. 2105 (1971)

Note 11. Agostini v. Felton, 521 U.S. 203, 117 S. Ct. 1997 (1997)

Note 12. Lynch v. Donnelly, 465 U.S. 668, 104 S. Ct. 1355 (1984)

Note 13. Cty. of Allegheny v. ACLU, 492 U.S. 573, 109 S. Ct. 3086 (1989)

Note 14. Lee v. Weisman, 505 U.S. 577, 112 S. Ct. 2649 (1992)

Note 15. Zelman v. Simmons-Harris, 536 U.S. 639, 122 S. Ct. 2460 (2002)

Note 16. Epperson v. Arkansas, 393 U.S. 97, 89 S. Ct. 266 (1968)

Note 17. Edwards v. Aguillard, 482 U.S. 578, 107 S. Ct. 2573 (1987)

Note 18. Ill. ex rel. McCollum v. Bd. of Educ., 333 U.S. 203, 68 S. Ct. 461 (1948)

Note 19. Zorach v. Clauson, 343 U.S. 306, 72 S. Ct. 679 (1952)

Note 20. Engel v. Vitale, 370 U.S. 421, 82 S. Ct. 1261 (1962)

Note 21. Wallace v. Jaffree, 472 U.S. 38, 105 S. Ct. 2479 (1985)

Note 22. Newdow v. United States Cong., 328 F.3d 466 (9th Cir. 2002)

Note 23. Newdow v. Rio Linda Union Sch. Dist., 597 F.3d 1007 (9th Cir. 2010)

Note 24. N.H. Rev. Stat. Ann. § 194:15-c

Note 25. Freedom from Religion Found. v. Hanover Sch. Dist., 626 F.3d 1 (1st Cir. 2010)

\section{Copyright Disclaimer}

Copyright for this article is retained by the author(s), with first publication rights granted to the journal.

This is an open-access article distributed under the terms and conditions of the Creative Commons Attribution license (http://creativecommons.org/licenses/by/3.0/). 